\title{
Creating Liberal-Internationalist World Citizens: League of Nations Union Junior Branches in English Secondary Schools, 1919-1939
}

\author{
Name: Dr Susannah Wright \\ Email: susannahwright@brookes.ac.uk \\ Address: School of Education, Oxford Brookes University, Harcourt Hill, Oxford, OX2 9AT, UK \\ Twitter: @susannahlwright
}

\begin{abstract}
The League of Nations Union (LNU) was one among the many organisations, in different countries, that promoted internationalist education among the young in the interwar years. But it was a particularly large and prominent one and appealed to a wide cross-section of teachers and pupils in English schools. LNU junior branches were established in many English secondary schools. Occupying a space at the intersection of youth organisations, a larger political movement, and the school itself, these junior branches were part of a wider agenda of active citizenship through extra-curricular means. Their focus was a liberalinternationalist version of "world citizenship" which accommodated existing loyalties to nation and empire as well as loyalty to the wider international sphere, and which sought peace but would countenance the controlled use of armed force against breaches of international agreements. Case studies of junior branches in two girls' schools and two boys' schools draw on school magazines and other relevant sources to shed light on what world citizenship could look like in different school contexts. The traditions and cultures of these different schools, the LNU's ideals and resources, and changing international events, all emerge as important shapers of junior branch activities, and the response to what junior branches offered. Examining the micro-contexts of junior branches in schools contributes new, grounded, insights to a historiography of internationalist education, indicating ways in which ideals of liberal-internationalist world citizenship were negotiated, promoted, taken up, passed on, altered, and, sometimes, challenged or ignored.
\end{abstract}

\section{Keywords}

Internationalism; citizenship; youth movements; peace; schools 


\section{Creating Liberal-Internationalist World Citizens: League of Nations Union Junior Branches in English Secondary Schools, 1919-1939}

After 1919, many voluntary associations in England (and indeed internationally) proved keen to avoid a repeat of the horrors of the First World War, and to promote a united and peaceful new world order. 1 Attaining these goals meant changing the thinking and actions of governments and of individual citizens. The League of Nations Union (LNU), formed on 8 November 1918 to promote the newly established League of Nations among politicians and a wider public, stands out among the organisations working in England (and Britain as a whole) towards these lines. With its paid-up membership peaking at 406,868 in 1931 it was one of the largest voluntary associations of the interwar years.2 A mass political movement, it sought to attract varied political and religious ideological constituencies to its liberal-internationalist project. 3 Its objects were to "secure the whole-hearted acceptance by the British people" of the newly-founded League of Nations, "to foster mutual understanding, goodwill and habits of co-operation ... between the peoples of different countries", and "to advocate the full development of the League of Nations" in order to "guarantee the freedom of nations ... maintain international order and finally liberate mankind from war and the effects of war". 4 The educational imperative behind these goals is clear. Informal educational provision for an adult public was provided through its publications, pageants, exhibitions, and local branch meetings.5 And from 1919 to 1939 the LNU reached out to the captive audience of young people compelled to spend much of their time in schools, promoting what contemporaries labelled League of Nations

\footnotetext{
1 Martin Ceadel, Semi-Detached Idealists (Oxford: Oxford University Press, 2000) and Martin Ceadel, Pacifism in Britain 1914-1945 (Oxford: Clarendon Press, 1980). The focus on England is determined by differences in educational administration, legislation, and traditions of schooling, in the British home nations which it would be beyond the scope of this article to explore.

2 A. C. F. Beales, The History of Peace (London: G. Bell \& Sons Ltd, 1931), 322 (41 League of Nations societies were established in member states by 1930); Helen McCarthy, The British People and the League of Nations (Manchester: Manchester University Press, 2011), 4. The LNU was an amalgamation of two existing organisations; the League of Nations Society (founded May 1915) and the League of Free Nations Association (founded June 1918), both of which campaigned for a new institution of international governance. See Donald S. Birn, The League of Nations Union 19181945 (Oxford: Clarendon Press, 1981), 6-11.

3 Liberal internationalism in the interwar years involved advocacy of a peaceful and interconnected international political and legal order, maintained through processes of collective security and arbitration organised through international institutions like the League of Nations. For the most part, the rights of democratic nation states and the legitimacy of imperial claims were respected and recognised. The LNU's liberal internationalism contrasted with communist and fascist internationalism, and other contemporary visions of a purely pacifist world order or a worldstate. See Patricia Clavin, "Introduction: Conceptualising Internationalism between the World Wars," in Internationalism Reconfigured, ed. Daniel Laqua (London: I.B. Tauris \& Co. Ltd, 2011), 1-14, at 5-6; Daniel Gorman, "Liberal Internationalism, the League of Nations Union, and the Mandates System," Canadian Journal of History 40 no. 4 (2005): 449-77.

4 League of Nations Union (LNU), Annual Report for 1925 (London: LNU, 1926), 3. For in-depth studies of the LNU see Birn, League of Nations Union 1918-1945 and McCarthy, British People.

5 Helen McCarthy, "The League of Nations, Public Ritual and National Identity in Britain, c.1919-56," History Workshop Journal 70 (2010): 108-32.
} 
teaching, through timetabled lessons and extra-curricular activities. 6 These efforts did not go unchallenged; some educationalists condemned the use of schools for explicitly political purposes.7 Still, League of Nations teaching was taken up by all but very few local education authorities in England. It was approached in a variety of ways and, commentators suggested, with differing levels of commitment; this variety is evident in the discussion that follows.8

League of Nations teaching in England was part of a wider pattern of internationalist education, intellectual exchange, and youth movement activity, which has received considerable scholarly attention. Such activity, which could variously be allied to patriotic and pacifist ideals, both pre-dated and post-dated the interwar years period.9 But from 1919-39 it became evidently increasingly attractive to a wide range of institutions and organisations, as evidenced by the number of youth movements which displayed, at this time, to a greater or lesser extent, an internationalist orientation. 10 Interwar years internationalist education also took on new forms shaped, in part, by the new organisational formations and geo-political configurations that emerged after the First World War, and which were often limited or stopped altogether during the Second World War. Thus the League of Nation's own complex of networks and committees formed sites of educational activism within which attempts were made to shape the school curriculum, and history teaching In particular, in member states, 11 whilst feminist transnational networks with

6 B. J. Elliott, "The League of Nations Union and History Teaching in England: A Study in Benevolent Bias," History of Education 6, no. 2 (1977): 131-41; McCarthy, British People, 103-31; Susannah Wright, Morality and Citizenship in English Schools. Secular Approaches, 1897-1944 (Basingstoke: Palgrave Macmillan, 2017), chapter 6.

7 J. L. Morison, letter to the editor, The Times, July 8, 1927, 15; “The League of Nations and the Schools," Journal of Education, July 1927, 485-6.

8 Board of Education, Report on the Instruction of the Young in the Aims and Achievements of the League of Nations (London: HMSO, 1932). The Board of Education never made League teaching compulsory but supported it through guidance for teachers (Board of Education, Handbook of Suggestions for the Consideration of Teachers and Others Concerned in the Work of Public Elementary Schools (London: HMSO, 1927, Appendix B).

9 Sandi E. Cooper, Patriotic Pacifism. Waging War on War in Europe, 1815-1914 (Oxford: Oxford University Press, 1991), esp. 41-2, 63, 78-80; Henrik Åström Elmersjö and Daniel Lindmark, "Nationalism, Peace Education, and History Textbook Revision in Scandinavia, 1866-1940," Journal of Educational Media, Memory, and Society 2 no. 2 (2010): 6374; Akira Iriye, Cultural Internationalism and World Order (Baltimore: John Hopkins University Press, 1997), esp. chapters 2 and 3; Robert Sylvester, "Mapping International Education. A Historical Survey, 1893-1914," Journal of Research in International Education 1 (2002): 90-125;

10 Many youth movements in the interwar years developed at least partly internationalist orientations and activities. Kristine Alexander, "The Girl Guide Movement and Imperial Internationalism in the 1920s and 1930s," Journal of the History of Childhood and Youth 2 no. 1 (2009): 37-63; Scott Johnston, "Courting Public Favour: The Boy Scout Movement and the Accident of Internationalism, 1907-29," Historical Research 88 no. 241 (2015): 508-29; Tammy Proctor, On my Honour (Philadelphia: American Philosophical Society, 2002); D. Prym, "The Woodcraft Folk and the Labour Movement 1925-70," Journal of Contemporary History 18 no. 1 (1983): 79-95; Nancy Sheehan, "Junior Red Cross in the Schools: An International Movement, A Voluntary Agency, and Curriculum Change," Curriculum Inquiry 17 no. 3 (1987): 247-66.

${ }_{11}$ Christophe Bechet, "La Révision Pacifiste des Manuels Scolaires. Les Enjeux de la Mémoire de la Guerre 14-18 dans I'enseignement Belge de l'Entre-deux-Guerres," Cahiers d'Histoire du Temps Présent 20 (2008): 49-101; Eckhardt Fuchs, "The Creation of New International Networks in Education: The League of Nations and educational organisations in the 1920s," Paedagogica Historica 43 no. 2 (2007): 199-209; Maria-Christina Guintella, "Enseignement de l'Histoire et Révision des Manuels scolaires dans I'Entre-deux-Guerres", in Pistes Didactiques et Chemins d'historiens, ed. Marie-Christine Baquès, Annie Bruter, Nicole Tutiaux-Guillon (Paris: L'Harmattan, 2003); Ken Osborne, “Creating the 'International Mind': The League of Nation's Attempts to Reform History Teaching, 19201939," History of Education Quarterly 55 no. 2 (2016): 213-40. 
internationalist aims connected with the League of Nations and its educational agendas.12 Much existing research focuses on organisations and institutions that prioritised and promoted internationalist education. My focus is somewhat different; I examine the ways in which internationalist educational was experienced and promoted in schools on the ground, through case studies of LNU junior branches in four English secondary schools. This approach situates the LNU's internationalist educational endeavours as a component of a range of informal but still school-based learning activities that constituted extra-curricular life in the English secondary school. It locates these efforts within a wider set of traditions and priorities in these schools which could support, or could challenge, junior branches' aims, and sometimes both.

From 1919 to 1939, the LNU promoted junior branches as effective mechanisms for creating world citizens in English schools.13 The LNU wanted school pupils to gain knowledge of the aims, machinery and activities of the League of Nations, and international affairs more generally, but aimed to change hearts as well as minds. "New knowledge alone", it argued, "without some change of feeling and purpose, will not suffice to make international co-operation the normal method of conducting world affairs. A sense of world citizenship has to be created." This "sense of world citizenship", the LNU claimed, would emerge particularly out of extra-curricular activities, which would "lend themselves more naturally than formal lessons" to bringing about the change of feeling and purpose desired.14 These suggestions chime with wider contemporary arguments whereby extra-curricular activities in schools - and secondary schools in particular - were deemed training in active citizenship (or "self-activity"); pupils would learn to contribute to political debate and respond to humanitarian need.15 Creating citizens, the LNU noted, was an educational aim of long-standing (and one which has been explored by a growing body of research).16 But the form of citizenship to be promoted had to go beyond the boundaries of the nation state and be suitable for what was deemed to be an emerging "co-operative world". 17 It would involve pupils recognising rights and obligations in relation not only to their nation but also to a wider international community. The

12 Joyce Goodman, "Working for Change across International Borders: The Association of Headmistresses and Education for International Citizenship," Paedagogica Historica 43 no. 1 (2007): 165-80; Marie Sandell, The Rise of Women's Transnational Activism (London, New York: I.B. Tauris, 2015).

13 The LNU Education Committee was disbanded in July 1939 and was reconstituted as a semi-autonomous body, the Council for Education in World Citizenship. My study ends at this point as this development meant significantly weaker ties to the LNU and a qualitative shift in the form and focus of school-based internationalist extra-curricular activity. Moreover, numbers of CEWC branches were very low during the Second World War; this appears to represent a hiatus in organisationally-focused internationalist extra-curricular activity which is evident in my case study schools, none of which document CEWC branches during the Second World War.

14 LNU, Declaration Concerning the Schools of Britain and the Peace of the World (London: LNU, 1927), 12, 14-15. 15 Association for Education in Citizenship, Training for Citizenship (Oxford: Oxford University Press, 1935), 31; J. L. Paton, "Work and Play out of School," Journal of Education, July 1927, 518; Sheehan, "Junior Red Cross in the Schools".

16 For the English context alone, recent research addressing citizenship in educational contexts includes: Tom Hulme, "Putting the City Back into Citizenship: Civics Education and Local Government in Britain, 1918-45," Twentieth Century British History 26 no. 1 (2015): 26-51; Benjamin Lammers, "'The Citizens of the Future': Educating the Children of the Jewish East End, c.1885-1939," Twentieth Century British History 19 no. 4 (2008): 393-418; Wright, Morality and Citizenship in English Schools; Peter Yeandle, Citizenship, Nation, Empire: The Politics of History Teaching in England, 1870-1930 (Manchester: Manchester University Press, 2015).

17 LNU, League of Nations Union Yearbook for 1933 (London: LNU, 1933), 25. 
international community envisaged by the LNU was very much an imagined one centred on the institution of the League of Nations itself and its member states. World citizens might not often interact, face to face, with their counterparts in other countries. But they would, the LNU suggested, share attitudes and behaviours such as "a positive desire for international justice and a sense of world loyalty", and the recognition of "a moral obligation towards every other being in the world, irrespective of colour, race or creed".18

Despite this ambition and inclusive rhetoric, the LNU's liberal-internationalist version of world citizenship was framed by the victors of the First World War, and an educated, mostly male, elite among them. No fundamental challenge was offered to commitment to nation state and empire. The LNU, in keeping with the liberal internationalist project more broadly, claimed not to undermine but to supplement existing national and imperial loyalties. It envisaged a hierarchy of nation states and races and cultures, illustrated most clearly in the League of Nations mandate system.19 And as a pacificistic body it recognised that avoiding major conflict might require the controlled used of armed forces in situations where nation states had contravened international regulations and arbitration had failed. A minority of members favoured the purely pacifist stance of avoiding armed conflict at all costs.20 But the LNU's official stance had to accommodate the promotion of peace, and provision for the minimum of military personnel and armaments required to intervene to put a stop to disputes or displays of military aggression. Junior branches encountered these hierarchies, inconsistencies, and complexities of liberal internationalism, which were filtered through the hierarchies of gender, class, and knowledge, and the varied traditions and cultures, of English secondary schooling.

The benefits of examining individual educational institutions from those aimed at adults in Paris and Geneva, 21 to English girls' schools, 22 have been demonstrated by existing studies. Here, I argue for the value of comparative insights too, as these can highlight the ways in which different institutions, with their different traditions and cultures, responded to internationalist educational agendas. This article therefore draws on case studies of junior branches in four English secondary schools: two girls' day schools (Central Foundation Girls' School in London and Manchester High School for Girls), and two boys' schools, Brigg Grammar School in Lincolnshire, and Solihull School in the Midlands, both endowed grammar schools in receipt of LEA money, and, as was typical of many boys' schools at the time, with day and boarding pupils.

\footnotetext{
18 LNU, League of Nations Union Yearbook for 1937 (London: LNU, 1937), 29-30; LNU, Junior Branches of the League of Nations Union (London: LNU, 1936), 14; Benedict Anderson, Imagined Communities (London: Verso, 1983).

19 Gorman, "Liberal Internationalism, the League of Nations Union, and the Mandates System"; McCarthy, British People, 132-54.

20 Ceadel, Pacifism in Britain, 3-5.

21 Katarina Lepännen, "Education for Internationalism at the Nordic School for Adult Education in Geneva 1931-1939," History of Education 40 no. 5 (2011): 635-49; Jehnie I. Reis, "Cultural Internationalism at the Cité Universitaire: International Education Between the First and Second World Wars," History of Education 39 no. 2 (2010): 155-73; Christopher Watkins, "Inventing International Citizenship: Badminton School and the Progressive Tradition between the Wars," History of Education 36 no. 3 (2007): 315-38.

22 Goodman, "Working for Change across International Borders"; Watkins, "Inventing International Citizenship".
} 
These four schools were selected for their geographical range, their varied histories and traditions, their different pupil bodies, and inevitably the availability of relevant documents.23 I make extensive use of school magazines, supplemented by other school-based sources where available. With their regular reports of the activities of school societies, school magazines provide valuable insights into individual junior branches' activities. They offer a pupil perspective - or at least the perspective of the branch secretary or eager member who wrote the school magazine report - which is rarely found in the records and publications of the LNU itself. The focus of the school magazine, moreover, is on the life and culture of a school community. Internationalist education within junior branches, therefore, is presented in the school magazine as one aspect of this life and culture, and not the primary focus that it is in LNU records and outputs. The small number of schools examined provides only a snap-shot of junior branch activity; it is impossible to generalise widely. A systematic comparison of junior branches based on a comprehensive typology of schools is not attempted here; suggestive insights, only, are offered. The limitations of the sources should also be noted; for school magazines these include the possibility of staff or pupil editorial oversight, if not censorship, and a tendency to relate only the voices of the most enthusiastic and eloquent pupils. 24

Junior branches formed part of the mix of activities, rituals, and groupings that together constituted the English secondary school community of the interwar years, but they also connected with the wider community of a mass political movement. They could benefit from pupil enthusiasm and the patronage of school staff or LNU headquarters. They could suffer from competition from other interests and activities, or from lack of teacher and pupil attention. They could fit well with, or clash with, traditions and cultures dominant in individual schools. Enclaves of liberal internationalism within the wider school community, they enabled pupils to connect with the imagined community of the world citizen, and, in theory at least, to develop the ideals and dispositions that the LNU's vision of world citizenship required. Yet individual junior branches, though all linked to the same parent organisation, governed by its regulations, and with access to the same publications, did this in different ways and with varied results. The micro-contexts of junior branches in schools can suggest ways in which ideals of liberal-internationalist world citizenship were negotiated, promoted, taken up, passed on, altered, and, sometimes, challenged or ignored.

\footnotetext{
23 Most English secondary schools at the time were single-sex, though a few co-educational schools existed. 24 James Anthony Mangan, Athleticism in the Victorian and Edwardian Public School (Cambridge: Cambridge University Press, 1981), 243-50; Helen Proctor, "An Aristocracy of Talent? Describing Self and Other at an Early TwentiethCentury High School," History of Education 38 no. 2 (2009): 247-61; Catherine Sloan, "'Periodicals of an Objectionable Character': Peers and Periodicals at Croydon Friends' School," Victorian Periodicals 50 no. 4 (2017): 769-86; ongoing doctoral research by Ed Whiffin (Public schools, politics and associational culture in England 1900-1939, University College London - Institute of Education). School histories were consulted for each school. Extensive archival material exists for MHSG and CFGS, a less extensive collection for Solihull School, and none for Brigg Grammar Schools.
} 


\section{The League of Nations Union junior branch and the liberal-internationalist world citizen}

Apparently in response to requests from teachers, the LNU first authorised junior branches in 1920 for young people aged 16 and over. This effectively restricted junior branches to secondary schools and, despite the removal of age restrictions by 1930 , the junior branch remained predominantly a secondary school phenomenon throughout the interwar years.25 The LNU Education Committee offered suggestions for activities, and from 1932 an optional common scheme of work. It provided visiting speakers, and loaned out books, films, and lantern slides. Junior branches connected with one another through notices in LNU periodicals and conferences for junior branch leaders, and inter-branch activities were common in large urban areas. 26 Programmes of activity, however, were organised by individual junior branches themselves; despite common features, type and frequency of activities could vary as the case studies here show. From the mid-1930s, a hostile international situation led to disillusionment with the League of Nations and, by extension, the LNU. This took time to have a clear impact on the number of junior branches, which peaked at over 1500 in 1938.27 But by Autumn 1938, many long-standing branches had severed their links with the LNU Education Committee because they objected to the wider LNU's foreign policy lobbying. ${ }^{10}$ Some junior branches ceased operations completely. Others withdrew from the LNU but continued in a different guise, typically as a current or international affairs group. Some, of course, stayed open, retaining their affiliation with the LNU (including the Central Foundation Girls' School one), and new junior branches were opening in the early months of 1939. Still, widespread junior branch closure appears to have been influential in the decision to reconstitute the LNU Education Committee from July 1939 as a semi-autonomous body, The Council for Education in World Citizenship, which could focus on purely educational work.28

Junior branches organised lectures, study circles and debates, model assemblies, concerts, pageants, plays, fund raising for humanitarian purposes (or for the LNU itself), correspondence with children overseas, and travel. Members took part in study visits and camps organised by LNU headquarters. Teachers could see considerable potential in this range of activities which, taken together, offered a variety of engaging, and sometimes practical and active, pedagogies. Mary Clarke, Headmistress of Manchester High School for Girls, in 1928, argued that the activities of her school's junior branch were of "too great educational value to rank any longer as 'extras'", and could displace "some of the obsolete lumber of the

25 LNU Minutes of the Education Committee (hereafter LNUMEC), September 24, 1920, Records of the League of Nations Union (LNU Records), British Library of Political and Economic Science (BLPES). The LNU Education Committee in 1934 reported junior branches in c. $39 \%$ of secondary schools, but only in $2.5 \%$ of elementary schools, in England and Wales. LNUMEC, June 11, 1934. This was after reduction and removal of the minimum age of entry (LNUMEC, December 6, 1928, December 8, 1930).

26 LNU, Teachers and World Peace, $2^{\text {nd }}$ ed (London: LNU, 1929), 55-76; LNU, Annual Report for 1931 (London: LNU, 1932), 37; LNU, League of Nations Union Yearbook for 1933, 31; LNU, League of Nations Union Yearbook for 1936, (London: LNU, 1936), 42; LNU, League of Nations Union Yearbook for 1938 (London: LNU, 1938), 24; LNU, Annual Report for 1938 (London: LNU, 1939), 18.

27 The 1938 figure represented the total number of branches formed, including those that had ceased to pay their subscriptions. In July 1939, after a sifting exercise, only 649 were up-to-date on fees (i.e. 'active'). LNU Minutes of the Junior Branches Sub-Committee, March 1, 1938, November 29, 1938, July 6, 1939, LNU Records.

${ }_{28}$ "The Work and Policy of the League of Nations Union and of its Education Committee," filed November 21, 1938, LNUMEC; Derek Heater, Peace through Education (Lewes: Falmer Press, 1984), 41-5. 
regular curriculum and stereotyped examination syllabuses".29 The junior branch, moreover, branch leader Winifred Jay of Central Foundation Girls' School suggested, would help pupils recognise their role within a larger movement: "They pay their small yearly subscription, they often wear the penny badge, and feel as much a member of the League of Nations Union as Lord Cecil himself." ${ }_{30}$ Other benefits were noted. The study-circle, debate or lecture could provide a "method of extending and consolidating knowledge", building on learning within timetabled lessons, while opportunities for public speaking, organising events, and supervising younger pupils, could "deepen the character". ${ }_{31}$ Plays, pageants, concerts and other "opportunities ... for dressing up" constituted a public ritual that provided entertainment and enjoyment, 32 and potentially, Helen McCarthy suggests, a cultural script that enabled pupils to describe and understand their individual and national identity in the post-First World War world. 33

Limitations were acknowledged within LNU circles. Alfred Zimmern, LNU Education Committee member and Professor of International Relations at the University of Oxford, condemned the "fancy-dress internationalism" of model assemblies, pageants, and plays for doing little to promote a "grasp of the principles for which the League and its machinery exist". He proposed "more fundamental and less recreative methods" .34 Even enthusiasts noted that large junior branch meetings were not conducive to a balanced discussion of the League of Nations' difficulties as well as its triumphs; this was better achieved through the "quiet atmosphere of the classroom". Stronger criticisms were voiced outside the LNU, with one correspondent in the educational press, for example, presenting the "dragooning" of pupils into school junior branches, alongside the "manipulation of the history lessons" which was more often the focus of comment, as the LNU forcing its "propaganda" into schools. 35

Anecdotally, activists noted considerably more junior branch activity in girls' schools than in boys' schools, an impression borne out through the crude barometer of the number of references to junior branches in LNU periodicals. 36 Not only were there, apparently, more junior branches in girls' schools, but those in girls' schools often lasted longer. This mirrored movement-wide gender dynamics. The LNU proved a female-heavy organisation; its leaders might have been men, but women outnumbered men among members on the ground. 37 Such dynamics were filtered through the cultures and traditions of secondary

\footnotetext{
29 Headway, July 1928, LNU Supplement, ii.

30 LNU, An Experiment in a Secondary School (London: LNU, 1924), 5.

31 Francis Sydney Marvin, The Nation at School (London: Oxford University Press, 1933), 158; LNU, An Experiment in a Secondary School, 6.

32 Headway, March 1924, 58.

33 McCarthy, "The League of Nations, Public Ritual and National Identity in Britain".

34 Board of Education, Report on the Instruction of the Young, 13; Alfred Zimmern, "Education in International Relations: A Critical Survey," Educational Survey, March 1932, 9-29, at 17.

35 LNU, An Experiment in a Secondary School, 4; Journal of Education, July 1927, 485-6.

36 Interview with Kathleen Gibberd, March 14, 1978, 8SUF/B/179, Oral Evidence on the Suffragette and Suffragist Movements 1974-1981 (8SUF), The Women's Library, BLPES; LNU data on junior branches do not differentiate between boys' and girls' schools. There are 157 references to junior branches in girls' schools in LNU periodicals between 1920 and 1939, and 59 references to junior branches in boys' schools (Sources: Headway (1920-39), League News (1932-39), LNU News Sheet (1932-39)).

37 See McCarthy, British People, 182-211 on gender dynamics within the LNU.
} 
schools. LNU Education Committee member FS Marvin, for example, suggested that behind the positive response to the League of Nations in girls' schools lay a spirit of "human passion and ... devotion" and humanitarian activism among those who promoted girls' secondary and higher education in the late nineteenth century. This spirit, he argued, continued to influence teachers in the interwar years (some of whom would have trained or worked with the older generation of educators that Marvin referred to). 38 Marvin's unstated assumption was that boys' secondary schools had alternative traditions which, if they did not clash with the LNU's aims, sat less easily alongside them. Among these might have been a military ethos, often revolving around an Officer Training Corps (OTC), and a culture whereby physical prowess, particularly in the form of games or other communal, organised activities like scouting, was associated with good character and masculinity. 39 The LNU seems to have recognised the need appeal more to boys, and offered its Nansen Pioneer Camps (which it advertised in distinctly masculine language as "[making] peace adventurous", and building "a vigorous harmony of body and mind") as an attractive alternative to more sedentary junior branch activities. These camps, which started in 1933, arrived too late for the junior branches at Brigg Grammar School and Solihull School.40 And on the question of militarism in schools, particularly in the form of the OTC, the LNU's pacificistic stance required that it remain officially neutral; members, however, disagreed among themselves on this issue.41 Generalisations like Marvin's might be backed up by overall patterns, but cannot be sustained in full. Large and successful branches in boys' schools did exist but appear to have been relatively rare. In 1934, Glasgow High School for Boys claimed to have the largest junior branch in Britain, with over 600 members, 42 whilst Bembridge School Junior Branch on the Isle of Wight reported enrolling every boy in the school.43 Not all girls' schools, moreover, were as enthusiastic as those studied here; at Roedean School, apparently, the junior branch was "ignored by many". 44 And even if general patterns were evident across the LNU movement, and across English schools, the context of the individual school could influence the way that LNU activism was actualised in that setting. This much is illustrated in the case studies of individual junior branches that follow.

\section{Four Schools and their Junior Branches}

Schooling in England, in the interwar years, was relatively decentralised in comparison with many countries. English teachers might have railed against the constraints of examination systems, education

38 Marvin, The Nation at School, 144.

39 See Mangan, Athleticism in the Victorian and Edwardian Public School. On the diffusion of a "public school culture" among grammar schools see James Mangan, "Manufactured" Masculinity (Abingdon: Routledge, 2012), chapters 12 and 18. A public school in England is a selective and expensive fee-paying independent secondary school.

40 LNU, Junior Branches, 27.

41 Magazine of Manchester High School for Girls (MHSG), June 1932, 15-16; December 1932, 2-4. For debates among LNU members see J. H. Badley, "The Effect of the O.T.C.," Headway, January 1926, 5; "The Effects of the O.T.C.," Headway, February 1926, 26-7; Headway, April 1930, LNU Supplement, i.

42 Headway, November 1934, 218.

43 League News, June 1934, 7.

44 Susan Major, Doors of Possibility: The Life of Emmeline Tanner 1876-1955 (Cambridge: Lutterworth Press, 1995), 283. 
codes, and funding and inspection regimes, yet international observers noted the freedom offered by the lack of a central government-prescribed curriculum. 45 In such a system, differences between schools could be accommodated and might even, within limits, have been encouraged. Each of these schools examined here negotiated its own position within the complex social and academic hierarchies of English secondary schooling. Each had to please pupils, satisfy parents (most secondary school places at the time were feepaying ones), and accommodate the favoured ideals and priorities of both the school's founders and current staff, as well as the demands of both universities and employers of students leaving the school. At the same time, with the exception perhaps of very few elite public schools, schools also had to find a place within the local civic sphere, and negotiate the needs, traditions, personalities, politics, and associational life of the local community. Sara Burstall, Headmistress of Manchester High School for Girls (MHSG) 18981924 , noted, with respect to these different constituencies, that "too often their requirements were opposed". 46 Yet, while accommodating such demands, individual schools, as communities, could also forge a sense of distinctive culture and ethos, "inventing" traditions - practices, rituals, school songs and mottos, school ideals - with the aim of reinforcing a sense of common identity among staff and pupils. 47

Central Foundation Girls' School (CFGS) was a municipal secondary school in London. In the interwar years it occupied premises opened in 1891 in Spital Square, London, but celebrated its c.1700 origins as a charity school in St Botolph's parish. The pupil body consisted mainly of East End girls, often working-class, and included many immigrants and a large "Jewish portion".48 Inspectors in the 1930s praised innovative teaching methods, a rounded curriculum which combined academic with applied and commercial subjects, and an emphasis on health and "general training for citizenship". But they also noted weaknesses: ageing and cramped buildings, a shortage of books, and a high proportion of pupils leaving clerical work at age 14 or 15 thereby sacrificing opportunities for further study.49 And CFGS as a municipal day school lacked the social cachet of other girls' schools of the time: it was not able to produce "the rightclass of candidate" for emigration to the empire in the eyes of the Colonial Intelligence League, for example.50 Manchester High School for Girls was established in 1874, funded in its early years by donations

${ }_{45}$ Olive Shropshire, The Teaching of History in English Schools (New York: AMS Press, 1936), 21.

${ }_{46}$ Sara Burstall, Retrospect \& Prospect. Sixty Years of Women's Education (London, New York, Toronto: Longmans, Green \& Co, 1933), 233.

${ }_{47}$ Gary McCulloch and Colin McCaig, "Reinventing the Past: The Case of the English Tradition of Education," British Journal of Educational Studies 50 no. 2 (2002): 238-53; Watkins, "Inventing International Citizenship". For the original seminal text see Eric Hobsbawm and Terence Ranger, eds., The Invention of Tradition (Cambridge: Cambridge University Press, 1983).

48 Central Foundation Girls' School (CFGS), Bicentenary Magazine 1726-1926, 4, 16, 32; CFGS, "Time Line: School History," at: http://www.central.towerhamlets.sch.uk/CFGS-Historical-Archive-Resources (accessed July 13, 2017). 49 Board of Education, Report of Inspection of Central Foundation Girls' School, Stepney, London, Held on $7^{\text {th }}, 8^{\text {th }}, 9^{\text {th }}$ and $10^{\text {th }}$ February, 1938, 2, 1/CFS/A/4/4/4, Records of the Central Foundation Girls' School (henceforward CFGS Records), Tower Hamlets Local History Library and Archives; Report of annual distribution of prizes, Hackney Gazette November 10, 1930, Volume of News Cuttings 1930-45, 1/CFS/A/11/2/2, CFGS Records.

50 CFGS, "Time Line: School History"; CFGS, Bicentenary Magazine, 58; Board of Education, Report of Inspection of Central Foundation Girls' School, 15; Records of the Colonial Intelligence League, County Organisation Sub-Committee Minutes, October 23, 1913, ICIL/1/7, BLPES. See Joyce Goodman, "'Their Market Value Must Be Greater for the 
and subscriptions from Manchester residents and an existing local endowment. By the interwar years, girls from Manchester's German, American and Jewish communities, and Belgian refugees who arrived during the First World War, studied alongside locally-born middle-class girls.51 The social standing of the school, and by extension its girls, was something which its leaders were determined to preserve; Sara Burstall in the 1920s sought to move the school to a "better neighbourhood" owing to "social deterioration" in the school's original location which was thought to have led to falling enrolment.52 Academic standing was valued too. Emphasis was placed on an education comparable to that received by boys, which emphasised theory, classics, and science, and encouraged progression to university. But opportunities for community and political activism and physical activity, also, were available outside the classroom through a wide range of sporting, musical, drama, literary and debating clubs, and societies supporting local charitable activity. 53 Solihull School was a charitable grammar school founded in 1560, in a market town outside Birmingham. This was not an elite school; it was tied to Warwickshire County Council till 1946, and its pupil body, which consisted of both day boys and boarders, included sons of skilled local artisans. Yet Solihull School had public school ambitions, losing "grammar" from its title in 1913, strengthening its house system, and investing from the Edwardian years in new buildings and ample playing fields.54"Church of England values" were encountered in the chapel and through religious instruction. Through the school's Officer Training Corps, formed in 1908 out of a cadet corps established ten years previously, strong links to the military were forged. But by the interwar years these older traditions of school life thrived among a growing range of clubs and societies.55 Brigg Grammar school for boys, again, was at an old institution (founded 1680/81) in another market town, this time in North Lincolnshire. Brigg, unlike Solihull, remained a grammar school, catering by the interwar years for a growing number of day and boarding pupils from

Experience They Had Gained': Secondary School Headmistresses and Empire 1897-1914," in Gender, Colonialism and Education, ed. Joyce Goodman and Jane Martin (London: Woburn Press, 2002), 175-98 at 180-81.

51 Joyce Goodman and Sylvia Harrop, “Governing Ladies: Women Governors of Middle-Class Girls' Schools, 18701925," in Women, Educational Policy-Making and Administration in England, Authoritative Women Since 1880, ed. Joyce Goodman and Sylvia Harrop (London: Routledge, 2000), 37-55, esp. 38-9; Manchester High School for Girls, A Brief History of Manchester High School for Girls (Manchester: MHSG, 2012), 2-4.

52 Burstall, Retrospect \& Prospect, 283-6.

53 Mary Clarke, A Short Life of Ninety Years (Edinburgh: Caledonian Press, 1973), 43-4; Manchester High School for Girls, A Brief History of Manchester High School for Girls, 2-4; Cecile L. M. McInnis, "English Schools do Charity Work; Give Piano Lessons," School, NA 1931 St3, MHSG Archives. MHSG was among the 14 girls' schools sending six or more pupils to Oxford or Cambridge Colleges in 1891-93 and was one of the 34 doing so in 1911-13. Janet Howarth, "Schools, Safety-Nets and Educational Ladders: The Classification of Girls' Secondary Schools, 1880-1914," Oxford Review of Education 11 no. 1 (1985), 59-71, at 70

54 John C. Loynton, A History of Solihull School, 1560-2010 (Solihull: Solihull School, 2010), 15, 30; John Burman, Solihull and its School (Birmingham: Cornish Brothers Limited, 1939), 56-8. The headmaster was finally admitted to the Headmaster's Conference in 1948. "Solihull School: Our History," at:

http://www.solsch.org.uk/page/?title=Our+History\&pid=11 (accessed 13 July 2017). The house system, first developed in elite boarding schools, was common in boys' secondary schools of the interwar years. It offered an organising structure for social life in the school (for example around sleeping arrangements for boarders and sporting fixtures).

55 Burman, Solihull and its School, Foreword, 47, 55-7; Loynton, A History of Solihull School, 15, 125. All headmasters of the school till 1920 had been reverends. In 1908, as part of wider army reforms, existing school cadet corps, which had been founded on an ad hoc basis, were reorganised into OTC, a uniformed force with standardised regulations, supported by the War Office. 
across North Lincolnshire which the school struggled to house in its ageing buildings. Ex-pupils, however, recalled some of the form, if not the substance, of public schools - prefects, houses, and intellectual snobbery. 56 Sporting fixtures, particularly cricket and football, dominated time outside lessons, the number of pages devoted to them in the school's magazine suggests. By the 1930s, however, a rifle club, scout troop, debating society, philatelic society, gardening club, musical society, and school orchestra, alongside the LNU junior branch, offered alternative pursuits. By the time that school's junior branch was formed in 1928, the school's cadet corps, formed in 1916, had been disbanded; overt militarism was apparently not in keeping with the "prevailing atmosphere" in the school at the time.57

In 1921 an LNU junior branch was opened at CFGS, following a lecture to the school by a police court magistrate on the work of the League of Nations. This was the first junior branch of the four to be founded by some six years and it was also the one that was to last the longest, continuing its operations till the demise of the LNU Education Committee in 1939, and moving to the CEWC sometime before 1946.58 The CFGS Junior Branch appears to have been a particularly active and ambitious one, and its work was publicised by the LNU.59 Membership levels were consistently high, with nearly all pupils in the Fourth Form and above who were eligible to join, apparently, doing so.60 A wide-ranging programme included talks (by staff, students and visiting speakers), model assemblies, debates, quizzes, League birthday parties, plays, pageants, concerts, fund-raising, and correspondence with pupils overseas. Success in regional inter-branch competitions, and international recognition (a FIDAC (Fédération Inter-alliée des Anciens Combatants) peace medal in 1930), suggests that this varied activity did not detract from the depth of pupils' knowledge and understanding as judged externally.61 The annual League birthday party, from 1925 onwards, was a celebratory ritual. Girls dressed up in national costumes. A birthday tea with a League cake, and the distribution of membership cards to the Fourth Formers who could now join, was followed by a dose of expert knowledge given through a rousing lecture from a suitably qualified external speaker. A disarmament banquet in Autumn 1931 combined speeches from pupils acting as statesmen of the leading nations of Europe with the drinking of lemonade and eating of sweets. The junior branch could also engage

${ }_{56}$ F. Henthorn, The History of Brigg Grammar School (Brigg: The Lincolnshire Standard Ltd, 1959), chapters 2 and 3; F. Henthorn, "Narrative, 1919-1969" in Brigg Grammar School ... 1919-1969, ed. F. Henthorn (Brigg: Foundation Governors, 1969), 3, 13-14, 22-3.

57 The Briggensian, inter alia; Henthorn, "Narrative," 28-9.

58 Central Foundation Girls' School (CGFS) Magazine, March 1922, 6; February 1946, 23. No volumes of the school magazine are available between 1939 and 1946.

59 LNU, An Experiment in a Secondary School.

$60 \mathrm{lbid}$., 7. 'Form' in the secondary school context meant a year group; the Fourth Form was for pupils typically aged 14-15. Smaller groups studying a particular set of subjects (for example the Commercial Form in CFGS), or categorised by ability, could also be identified this way.

61 CFGS Magazine, March 1926, 9-10; May 1928, 14-16; February 1930, 20; May 1932, 4-6; February 1934, 9-10; March 1939, 10-11. FIDAC peace medals were awarded annually to educational institutions among the allied countries for their work in promoting peace. FIDAC was founded in 1920 as an international association of First World War veterans' movements from allied countries. Former enemy nations were not admitted. Much of its effort was directed to international understanding and peace-related activity. FIDAC also cared for veteran invalids, war widows, and orphans. See: The Great War and Veteran's Internationalism, ed. Julia Eichenberg and John Paul Newman (Basingstoke: Palgrave Macmillan, 2013). 
in overt political activism, associating itself in 1934 with the "immediate work" of a local women's anti-war campaign. 62

Support for the League of Nations generally, and the junior branch specifically, was deeply embedded in the life of the school. There are parallels with the immersive culture of internationalism that Christopher Watkins describes in Badminton School. Songs and poems about the League of Nations were published in the school magazine, and branch activities featured regularly in the "Form Notes" in each issue. ${ }_{63}$ Girls in the Commercial Form typed notes and distributed letters for local adult LNU branches within the scope of their ordinary studies. This is one example of the efforts made to stimulate LNU activity locally, beyond the school ("helping to spread abroad the spirit of the League of Nations"), and to make links with the wider LNU movement.64 CFGS junior branch members helped to form new junior branches in the local area, often on the back of performances of branch members' songs and plays.65 Girls were also encouraged to join youth or adult branches once they left the school, and it was claimed that nearly all did so. Interviews with pupils before they left the school, letters of introduction to local adult branches, and the regular involvement of former pupils in junior branch activities, including a lecture by an ex-pupil who went on to become "well-known in League of Nations circles", seem to have provided the stimulus needed.66 The other schools examined here did not connect with the wider LNU movement to the same extent.

Features of the junior branch, and the school more widely, might account for this record of enthusiasm and activity. Firstly, the junior branch was supported and guided throughout its existence by Winifred Jay, senior history mistress and Fourth Form tutor. Winifred Jay - always Miss Jay in the school magazine - started at CFGS in 1913. By the time she took on the junior branch she was already an established member of staff. 67 She was assisted over the years by another historian, Miss Rosenberg, two science teachers - Miss Menzies, science teacher in the early 1920s who was to become headmistress on her return to the school in 1930, and Miss Carter - and Miss Ryan, physical mistress.68 But Miss Jay was very much in charge. She designed and co-ordinated activities, organised visiting speakers, secured the loan of teaching aids from LNU headquarters, 69 and even hosted garden parties for junior branch members at

62 CFGS Magazine, March 1925, 8-9; May 1932, 4-6; February 1934, 11-13.

63 Watkins, "Inventing International Citizenship". The first form notes can be found in CFGS Magazine, March 1925, 17-18; the same issue (on page 33) contains one of the many examples of songs and poems.

${ }_{64}$ CFGS Magazine, May 1932, 4-6; May 1928, 14-16, quote at 16.

65 For example, CFGS Magazine, March 1923, 8-9; March 1925, 8-9.

${ }_{66}$ CFGS Magazine, March 1924, 8-9; February 1930, 23-24; May 1931, 6-7 (quote at 7); LNU, An Experiment in a Secondary School, 8.

67 CFGS Magazine, February 1946, 10-11, 23.

${ }_{68}$ CFGS Magazine, March 1924, 8-9; March 1925, 8-9; May 1931, 11; February 1934, 12; February 1936, 20; Meeting December 8, 1927, Minute Book of Mistresses' Meetings 1922-28, 1/CFS/A/1/6/4; Staff Register 1898-1953, $1 / \mathrm{CFS} / \mathrm{A} / 2 / 4 / 3$, CFGS Records. Miss Menzies remained active in the junior branch even when she returned to the school as headmistress.

${ }_{69}$ CFGS Magazine, March 1924, 8-9; February 1930, 23-4; May 1931, 6-7; February 1934, 11-13; February 1946, 1011. 
her home.70 Outings, plays, pageants, tableaux, and other forms of drama and dressing up, featured prominently in the junior branch programme. This was in keeping with Miss Jay's approach to history teaching, which incorporated outings and drama, alongside book learning, and her enthusiasm for pageantry. ${ }^{71}$ Other schools might have offered pupils more leadership responsibilities, but a firm steer over many years from an experienced and committed teacher might have had its benefits. Secondly, this junior branch had strong links with the central committees of the LNU. It is not clear how the relationship first developed; the school's London location might have helped. The LNU published Miss Jay's account of the school branch's work in 1924, and, also, the celebratory League of Nations song written by an early pupil member, Esther Staub. Several ex-pupils went on to work at LNU headquarters. Miss Jay was a member of the LNU Education Committee from 1925 to 1938, and from 1936 sat on the Junior Branches SubCommittee.72 The junior branch must have benefitted from the positive publicity and the access to information and resources that these ties with the central LNU provided.

Thirdly, links with other junior and adult branches generated stimulating activities and useful contacts, and, through the involvement of ex-pupils, provided members with exemplars of internationalist activism as part of a school tradition that they should strive to uphold. A fourth factor was the political views of parents. In 1938, when other junior branch leaders noted parental opposition, Miss Jay reported no resistance. This she attributed to the liberal or socialist politics of most parents; liberals and socialists were the core political support groups for LNU generally.73 Finally, other extra-curricular activities do not appear, as they do in the magazines of the other schools, to the same extent as alternative demands on time and attention. Sporting activities were evident but seem to have been less prominent than at MHSG; lack of facilities might have proved an obstacle. There were no cadets, though the school did have its Girl Guides. A tentative case could be made for imperial or (mildly) militarist commitments featuring less at this school than the others. The school celebrated Empire Day each year but in a manner which emphasised learning about education in the colonies and celebrating the liberation of slaves. Whilst the LNU aimed at an internationalist reading of Empire Day more generally, such a reading was particularly distinctive at CFGS.74

An LNU junior branch was formed at Manchester High School for Girls in 1927, initially attached to the Literary and Dramatic Society, and from 1928 officially recognised as a junior branch of the LNU. As

\footnotetext{
70 CFGS Magazine, February 1936, 20; March 1939, 10-11.

71 CFGS Magazine, February 1946, 10-11. Miss Jay was a pageant master at the school's pageants in 1919 and 1926 (Programme for Peace Celebration July 1919, Pageant of Spital Square, Volume of News Cuttings 1930-45; CFGS, Bicentenary Magazine, 45).

72 LNU, An Experiment in a Secondary School; CFGS Magazine, March 1924, 8-9; LNU, Annual Report for 1925 (London: LNU, 1926), 36; LNU, League of Nations Union Year Book for 1936, 94-6; LNU, Annual Report for 1938 (London: LNU, 1939), 38-9; Press cutting (Miss Hanbridge's retirement), City Press, December 1929, Volume of News Cuttings $1899-$ 1930, 1/CFS/A/11/2/1, CFGS Records.

73 "The Work and Policy of the League of Nations Union and of its Education Committee", LNUMEC.

74 CFGS Magazine, inter alia; May 4, 1933 and May 1, 1935, Minute Book of Mistresses' Meetings 1928-39,

1/CFS/A/1/6/5, CFGS Records; McCarthy, British People, 103-04
} 
with CFGS, membership was open to pupils from the Fourth Form up. 75 Activities were more academically focused than at CFGS. The typical fare of one or two meetings a term mostly comprised talks or debates. Branch members could be addressed by staff, pupils, or visiting speakers. International events of the moment shaped activities (with Professor Roxby of Liverpool University speaking in 1933 about the Manchurian crisis), as did the priorities of the League of Union itself (in 1935 the junior branch organised a mock peace ballot modelled on the national event). 76 Study circles for Fourth Form pupils were run between 1928 and 1934. From 1929 these were led by older pupils, coached by one of the mistresses; girls could thus "[share] in the management of the branch". 77 Junior branch members were also expected to keep in touch with League affairs, and were reminded in the school magazine to read their news-sheet.78 Occasional large-scale events supplemented this regular activity. Model assemblies, held in 1928 and 1932, were reported in the local press. A group of pupils attended an international camp in Kiel-Schonhagen in 1932. For one attendee, writing in the school magazine, "by living, eating, and sleeping with people of another nation, one becomes conscious that national differences are not so great as might be supposed".79 Members also got involved in events organised by other local junior and adult LNU branches, attending a model assembly at Whalley Range School and local Armistice Day meetings in 1928. After about 1935, branch activities focused less on the LNU itself than on life and political ideals in other countries.

Encouraging sympathy and understanding, however, did not preclude hierarchies of race and nationality. A visiting speaker, Miss Mitchell, spoke in 1936 about the Institute of Pacific Relations. The students reporting the talk in the school magazine were impressed by the "energy and zeal displayed by ... men and women of the East in spreading culture in their respective countries." 80 The implication of a lack of pre-existing culture in the East is clear.

The wide range of extra-curricular activity at MHSG might have helped the junior branch to develop, but also meant many other events and causes competing for girls' time and attention. One pupil, Molly Greenhalgh, appears from 1932-34 as a junior branch study circle leader, secretary and then leader in the cadet corps, a cast member in school plays, lead speaker in Debating Society meetings, and assistant editor of the school magazine, which also published her prose and poetry. 81 Her energies were, perhaps, thinly spread. Some of the other extra-curricular activity was complementary to the junior branch ethos and ideals. The junior branch and debating society, for example, held joint events on topics including disarmament and the teaching of a universal language, and school visits to Germany have been noted

\footnotetext{
75 Magazine of MHSG, March 1927, 25; December 1928, 25.

76 Magazine of MHSG, December 1933, 3; July 1935, 33.

77 Magazine of MHSG, December 1928, 25; July 1929, 22; July 1934, 26, December 1934, 32.

78 Magazine of MHSG, July 1929, 22; March 1930, 26; December 1931, 21; June 1932, 16

79 Magazine of MHSG, July 1928, 2-3, 25; June 1932, 2; December 1932, 2-4; The 1928 Model Assembly and 1932

international camp were reported in the local press (Misc 1928 G2, NA1932 G1-G4, MHSG archives).

80 Magazine of MHSG, December 1928, 25; December 1936, 15-16.

81 Magazine of MHSG, December 1932; July 1933; December1933 and July 1934 inter alia.
} 
already - these continued to 1937.82 One might imagine that other activities like the cadets were potentially less of an ideological match. Yet pupils involved might not have felt any tension, the examples of Molly Greenhalgh and Muriel Spurgin, two active members of both the LNU and the cadets suggest.83

The headmistress, Miss Clarke, was consistently supportive, promoting the junior branch at school governors' meetings, and advertising its work at the wider networks she was involved in. 84 Her comments on the junior branch at the annual meeting of the Association of Headmistresses in 1928 have already been noted. Individual teachers were named and thanked for their help; Miss Hurford and Miss Whiteley, history teachers, and Miss Tiano who taught modern languages. 85 Even with this backing from teachers, the fortunes of the junior branch declined from the mid-1930s. Membership peaked at c.340 in 1930 and fell to 166 by 1936 . Such a pattern of initial enthusiasm followed by interest levels that plateaued, and then declined, was common among the school's societies.86 Yet falling numbers also corresponded in timing with escalating challenges facing the League and reflected changing attitudes to the League of Nations among a wider public. In Autumn 1938, owing to "the rather negative role which the League seemed to be playing in international events and the great confusion surrounding the events themselves", the junior branch was replaced by a news society, decoupled from the LNU. But, with the teacher who had worked with the junior branch continuing to offer advice and support, an interest in international affairs and events was retained. From 1948, in a more favourable political climate, a school United Nations branch, fully affiliated to CEWC, reported in the school magazine. 87 The future careers of a few individual junior branch members, moreover, suggest that an interest in the international sphere could continue into later life, but clear patterns cannot be established from the very small numbers for whom such information is available. 88

A visiting speaker in 1928, apparently, generated "great enthusiasm" for a junior branch at Brigg Grammar School. A committee of staff and students was formed, with the headmaster as president. There were typically one or two meetings a term, often talks by teachers and pupils and debates, on subjects like armaments, the mandates system, and the pressing international problems of the moment. Some prominent external speakers were secured, including Frederick Whelen and FS Marvin of the LNU, and Admiral Allen who "caused us to realise that it is more patriotic to support the League of Nations than to

82 Magazine of MHSG, December 1933, 21; July 1934, 25-6; March 1938, 11-12.

83 For suggestions of a lack of conflict for pupils see E. Lyttelton, "The Effect of the O.T.C.," Headway, December 1925, 226; "The Effect of the O.T.C.," Headway, February 1926, 26-7; J. F. Clarke, letter to the editor, The Times, June 17, 1930, 10.

84 Goodman, "Working for Change across International Borders".

85 Magazine of MHSG, July 1929, 22; July 1932, 26; March 1938, 35; MHSG Staff Register Vol. 3, 82, 86, 154, MHSG archives.

86 Magazine of MHSG, March 1930, 26; January 1936, 33; Christine Joy, previous MHSG archivist, personal communication, June 2012.

87 Magazine of MHSG, December 1938, 33; May 1948, 14.

88 MHSG's database of pupil destinations was searched for information about pupils named in the school magazine junior branch reports, but information for only very few could be released under UK data protection legislation. Many thanks to MHSG's archivists for their assistance. 
join the Army" 89 Members also read literature borrowed from LNU headquarters by Mr Gregory, house master and languages teacher; this is one of several references to ongoing teacher support.90 However, this junior branch, of the four examined, appears to have struggled the most to recruit members and attract decent audiences. "If more support is obtained from the school a more ambitious programme could be attempted", was the lament in the final report in The Briggensian April 1932, and the junior branch evidently lapsed after this date.91 There is no explicit statement explaining why this happened. Demands of the playing field were noted in junior branch reports as limiting activity, 92 and these demands were manifold, the many pages devoted to sporting fixtures in the school magazine suggest. The junior branch was not alone among Brigg's school societies in its difficulties with attracting members, 93 though some were more successful. Notwithstanding the school's aversion to overt links with military organisations, a milder version of militarism seems to have been acceptable. A rifles club and scout troop both flourished while the junior branch struggled. Whether this difference indicated boys' ideological and political commitments, or their preference for less sedentary activities for their spare time, is unclear.94 Also, little inter-branch activity was reported; Brigg's location limited access to the regional LNU structures and extensive networks of other local branches that were available to the other junior branches studied.95

Brigg's junior branch might, also, have suffered from the over-extension of key members. EW Kemp, for example, who acted as branch secretary in 1931 and 1932, and wrote the reports of branch activity, was also a prefect (head prefect by 1932), school librarian, organiser for the music society, and on the school magazine committee.96 Someone with this range of commitments might, ultimately, have lacked the time and energy to bolster the junior branch sufficiently. Yet this pupil offers a striking example of enthusiasm for the cause, and of pupils taking on the arguments, and even the language, of LNU publications:

We should like to see many more boys become members of the League of Nations' Union, as it must be fully realised that the League of Nations is the hope of the modern world and it is the duty of every citizen to support it to the best of his ability. 97

89 The Briggensian, July 1928, 25-6; July 1929, 67; December 1929, 30; December 1931, 122-3.

90 The Briggensian, July 1930, 76 (see also December 1930, 22); Mr Gregory remained at the school till 1948. Henthorn (ed), Brigg Grammar School, 33, 34, 99.

91 The Briggensian, April 1932, 164-5 for quote. See also December 1928, 4; July 1929, 67; July 1930, 76; December 1931, 122-3.

92 The Briggensian, July 1930, 76; December 1930, 22.

93 It was common for school societies to last only for a few years. Henthorn, "Narrative," 28.

$94 \mathrm{JL}$ Paton, ex-High Master of Manchester Grammar School, suggested in 1927 that typical junior branch activities were too sedentary for boys. Paton, "Work and Play out of School," 518.

95 Headway, July 1928, LNU Supplement, iv.

96 The Briggensian, December 1931, 104, 122-3; December 1932, 2. EW Kemp became Canon Kemp, chaplain to the Queen and an Exeter College theologian (R.G. Walker in Henthorn, "Narrative," 47).

97 The Briggensian, December 1931, 122-3. 
The closure of the junior branch, moreover, did not mean the end of interest in international affairs at the school; The Briggensian carried semi-regular editorial comments on the international situation up to the outbreak of the Second World War.98

Solihull School Junior branch was formed in Autumn 1928.99 A programme comparable to that at Brigg emerged, with meetings typically once or twice a term. In addition to talks and debates led by staff and pupils, the school branch attracted an impressive range of visiting speakers - Frederick Whelen (again) and Alec Wilson, both from LNU Headquarters, Commander Lewis of the Royal Navy, and RB Butler, Principal of Aston Technical College, to name a few.100 Pupils also benefitted from regional LNU structures, participating in the annual meetings for junior branches in the Birmingham district. International events of the time could influence the themes addressed by Solihull School's junior branch, as was the case elsewhere - "war in the Far East" and Adolf Hitler in 1933, for example. 101 The complaints about lack of interest at Brigg are not mirrored here, but the numbers voting in debates suggest relatively low membership levels, at least in comparison with the two girls' schools.102

Two themes emerge more prominently in reports of Solihull School's junior branch activities than for the other schools; this could be attributed partly to the length of the junior branch entries in the school magazine for this school, which allowed arguments and ideals to be explored. Firstly, in a school with strong links to the military, armaments and the military are emphasised in the choice of speakers and topics for lectures and debates. In March 1931, Commander Norman Lewis of the Royal Navy spoke about his own First World War experiences, claiming that there was "no romance or glory in war", and calling for disarmament. Later that year a debate was held on the motion that the school OTC should be abolished with seven voting for the motion and ten against; this has already been noted as a point of contention among LNU supporters more generally, and might have been particularly contentious in a school with strong links to the military. 103 Secondly, accounts of this junior branch are notable for their reference to an overtly Christian basis for avoiding war and promoting international understanding which was evident in the wider LNU movement, 104 but not so much in the reports of the other junior branches examined. Military coercion and war, in the context of a debate and a poster competition respectively, were described as "Unchristian". 105 In 1933 the president of the junior branch, Mr Osborn, reviewed The Christian and the Next War by Reverend Porter Goff, a prominent Nonconformist LNU advocate. This book discussed "the work of the Christian in freeing the world from war, and his share in any war that might yet take place". 106

\footnotetext{
98 The Briggensian, December 1935, 27-9; December 1938, 1.

99 The Shenstonian, December 1928, 74.

100 The Shenstonian, March 1930, 18-19; March 1931, 25-9; April 1933, 31-4.

101 The Shenstonian, March 1931, 27; March 1932, 33; April 1933, 32-4; March 1934, 39-40.

102 Membership numbers are not given in reports, but 17 voted during a debate about the school OTC (The

Shenstonian, July 1931, 81-2).

103 The Shenstonian, March 1931, 28-9; July 1931, 81-2.

104 McCarthy, British People, 79-102.

105 The Shenstonian, April 1933, 32-4; March 1934, 38.

106 The Shenstonian, December 1933, 146-7.
} 
The Anglican foundations and traditions of this school, or the individual beliefs of key members, potentially, had an influence here.

The junior branch at Solihull School was to last six years, becoming inactive at some point after the last report in The Shenstonian in March 1934.107 The school magazine gives the impression of it being something of a niche interest, with the school's scout branch and the OTC, for example, proving considerably more popular and consistently active and generating considerably more copy. Solihull's public school informed culture, with its emphasis on "character" and military and physical prowess was, perhaps, a difficult one for a junior branch to thrive in. 108 Yet staff were actively involved, with teachers (Mr HA Evans, French teacher, Mr J Dicker, Mr Osborn and Mr Forster), listed as committee members, and the headmaster Mr AR Thompson judging a poster competition and chairing debates.109 Moreover, as at Brigg, the idealism and enthusiasm of the branch committee members who wrote in The Shenstonian stands out:

It is in the schools that youth must be educated in the love of peace, and to regard arbitration as the normal method of settling international disputes. When this is attained we may say that the sacrifice of ten million lives will not have been in vain.110 Committed members of Solihull School's junior branch digested, and repeated, almost parrot fashion, standard LNU arguments about the importance of youth, the need to avoid armed conflict through arbitration, and the legacy of the First World War.

\section{Conclusion}

League of Nations Union junior branches functioned as enclaves of liberal internationalism within English secondary schools. They were a space for political awakening - perhaps of a naïve manner - for teenage members, enabling access to information, participation in performances and rituals, and, on occasion, direct political activism in association with the LNU and other 'adult' organisations. Enthusiasts among pupils aspired to be world citizens. They wanted to promote the League of Nations, prevent war, and unite the world. A minority of them spent time with young people overseas, others engaged in correspondence, some acted in plays and wore fancy dress, and all members of the junior branches examined spent time discussing and reading about international affairs and other countries with their peers and teachers. If mutual understanding with counterparts in other countries was sought it was often from within the school premises. The close examination of junior branches in four schools attempted here shows that ideals of peace and international understanding could jostle for priority with other commitments within the LNU's

\footnotetext{
107 The Shenstonian, March 1934, 38-9.

108 See Shropshire, The Teaching of History in English Schools, 85.

109 The Shenstonian, March 1934, 38-9. Of the staff on the junior branch committee named in the school magazine, only Mr HA Evans was listed in the available Staff Register, which only covers up to 1929 (and therefore might not include any staff employed between 1930-34). Therefore, subjects taught could not be identified for the others (Staff Register, 1879-1929, Solihull School Archives).
}

110 The Shenstonian, March 1930, 18-19. 
liberal-internationalist agenda, and with other demands on school resources and staff and pupil time and attention.

Junior branches formed part of a wider agenda of active citizenship through extra-curricular activity. The citizenship aimed at in the junior branch context was citizenship of the world, though nation state and empire remained significant. But junior branches' direct association with a mass-membership adult voluntary association distinguishes them in some ways from other school-based societies or branches of youth movements. The international political context, and the organisational resources and arguments of the LNU inflect pupils' school magazine accounts of junior branch activity; the successes of the parent body, but also the challenges and tensions experienced within the LNU more broadly, were brought into schools. Yet school-based case studies also suggest that local contextual factors could influence junior branches: the interests, commitments and preferences of staff members and the networks they were involved in, the ethos and traditions of the school, and the political views of parents and governors. Pupils' socio-economic background, and their nationality and religion, might have influenced the culture and priorities of the different schools, and the ways in which they engaged with the wider LNU agenda. The flexibility of liberal internationalism, arguably, enabled the junior branch to exist, if not always to thrive, in varied school settings. These school branches found different ways of engaging with the ideological terrain of the LNU's liberal-internationalist version of world citizenship, incorporating as it did a range of positions on peace and war, and embracing commitments to nation and empire which, if not directly in conflict with purely internationalist interests, did not always facilitate them or sit easily alongside them. Aspects of the school context intersected, in different ways for the four schools, with the gender differences identified among junior branches, and within the LNU, more generally.

Four schools offer a snap-shot of junior branch activity and can only suggest in an indicative way the factors that could influence junior branch activism in the secondary school context more broadly. They also say little about the many other forms that internationalist education could take in this period, perhaps in purer and less compromised, though never uncontested, forms in institutions set up explicitly for this purpose.111 Yet it is hoped that the grounded and highly contextual insights garnered here can contribute to wider debates, by shedding light on the intersection of internationalism with different priorities, commitments, cultures, and invented traditions within the school. School-based sources examined offer insights into pupil-activists' activities, aspirations, and ideals, and sometimes their challenges and disappointments too. They suggest some of the mechanisms through which liberal-internationalist ideas and ideals could be experienced, promoted, discussed, challenged, and ignored. My findings could be framed as success and failure, contrasting long-lasting and active branches with a large membership in two girls' schools with short-lived and less active ones in two boys' schools. But this might be missing the point as far as individual pupils, and possibly teachers, are concerned. The enthusiasm and commitment of some 
demonstrates that world citizens were created in boys' as well as girls' schools, at least in the moment committed to paper in the school magazine. And the international sphere remained a matter of interest even when junior branches lapsed into inactivity. This much applies to the schools studied in this sample. Further research could, usefully, explore whether patterns identified here were repeated across a wider range of schools. It could also ascertain whether belonging to smaller and potentially more coherent groupings (for example, co-educational schools, or elite public schools), or whether being in a different home nation - Wales, Scotland, Northern Ireland - made a difference. International insights related to junior branches in Britain's colonies and dominions, and to the equivalent of junior branches related to the League of Nations societies in other countries, could prove highly instructive too.

Historian's assessments are, inevitably, influenced by the point of time at which they write. One commentator in 1940 suggested that the LNU's internationalist educational efforts, with their aims of creating world citizens, created "satisfying emotions in the hearts of the believers" but invoked "a loyalty too wide to be effective".112 In 1954, Kathleen Gibberd, teacher and LNU activist, looking back on her interwar years efforts, felt that she and others "went too far with our wishful thinking and so added to the shock of disillusionment when war came". 113 In the longer term, however, world citizenship remained attractive for educators. The LNU Education Committee's successor body the Council for Education in World Citizenship lasted as an organisational entity till 2008, keeping the flame alive while taking care (unlike its predecessor) to avoid political lobbying. And the United Nations Association (UNA) in the present, aiming to "equip new generations of internationalists" and "encourage people to act on their responsibilities as global citizens", arguably retains similar commitments, though with an explicitly proUnited Nations focus. For both, school-based societies and extra-curricular activities have remained a central plank of their educational proposals. Yet their reach has been partial and regional, with success concentrated among academically-inclined grammar and fee-paying schools.114 Some of the tensions, divisions, and complexities that lay beneath the unifying discourses of liberal internationalism as experienced within LNU junior branches in schools in the interwar years remain evident in internationalist educational endeavours in the present day.

112 Times Educational Supplement, April 13, 1940, 135.

113 Kathleen Gibberd, Politics on the Blackboard: An Autobiographical Essay (London: Faber \& Faber, 1954$), 94$. 114 See United Nations Association (UNA-UK) History. At: http://www.una.org.uk/content/history [accessed 21 July 2017]; UNA-UK Model UN portal. At: http://www.una.org.uk/globe [accessed July 21, 2017]. CEWC merged with the Citizenship Foundation in 2008: Citizenship Foundation, 'News', September 15, 2008. At: http://www.citizenshipfoundation.org.uk/main/news.php?n645 [accessed August 3, 2017]. On CEWC's success in academically inclined and fee paying secondary schools see Heater, Peace through Education, chapter 6. 